\title{
視覚障害児専用の白杖の開発と評価
}

\section{Development activities of visually impairment children's new long cane}

\author{
Manabu YOSHIOKA ${ }^{* 1}$, Junichi SHIMIZU ${ }^{* 2}$, Hidemi KIZAKI ${ }^{* 3}$ and Hiroki NAKAO ${ }^{* 3}$ \\ ${ }^{* 1}$ Department of Human and Social Science, Kanazawa University \\ 2-10 Higashikenroku, Kanazawa-shi, Ishikawa 920-1302, Japan \\ ${ }^{* 2}$ Department of Occupational Therapy, Tokyo University of Technology \\ 5-23-22 Nishikamata, Oota-ku, Tokyo 144-8650, Japan \\ ${ }^{* 3}$ Kizaki Corporation \\ 561-2 Kamasu-uenodaira, Komoro-shi, Nagano 384-0061, Japan
}

\section{Received 24 July 2015}

\begin{abstract}
The long cane has been the most widely used mobility aid for the visually impaired people in spite of many other aid systems. The purpose of this study was to investigate canes that are currently being used at the special needs education school for the visually impaired and to produce new long canes experimentally and evaluate it for visually impaired children. An 8-item-questionnaire was developed and distributed to 71 all the Japanese special needs education schools for the visually impaired. $83.1 \%$ subjects who received the questionnaire completed it properly. The new types of the long cane were assessed for their ability to transmit the vibration and their sensitivity to tactile information, flexibility, and durability. The materials that are used in new long cane shafts were carbon fiber, aluminum and composite material of carbon fiber and aluminum at three kinds of the most commonly used materials. The tips that are used in new long cane were standard (pencil), marshmallow, and teardrop at the types of three categories. According to questionnaire results, the visually impaired children tend to use a straight cane, and a rubber golf grip standard-type cane tip in the special needs education school for the visually impaired, even though there are many kinds of cane tips. In these experiments of the new long cane, it was found that the lightweight canes, the regulating mechanism of cane's lengths and the combination of tips and grip might be associated with a visually impaired children's performance.
\end{abstract}

Key words : Long cane, Tip, Shaft, Grip, Visually impaired children

\section{1. 緒言}

移動社会である現代において視覚障害者に対する歩行支援は社会生活を営む上で必要不可欠なものとなってい る．彼らが単独歩行の際に使用寸る補助システムとして，白杖，電子装置，点字ブロックなど数多くのシステム が世の中に存在し，さらに少数ではあるが盲導犬も利用されている。これらの補助システムは，視覚障害者が単 独歩行時に直面する問題を解決するものとして考案されたものばかりである，その中でも特に白杖の基本デザイ ンは，1940 年代にリチャード・フーバーによって紹介された．それ以前まで白杖は木製であり短く，重く，扱い 難いものであった(Hoover, 1946，1962). しかし，アルミニウム製の白杖が新たに開発され，軽く，扱いやすく， 振動伝達性が向上した（Ball，1964）。それ以降も白杖はさらに開発が進められ，現在ではおそらく，視覚障害者 にとって最も効果的な移動自助具となっている（Foulke，1975）。白杖は，第一に体を守るバンパーの役割，次に 手指の触覚から情報伝達取得のプローブの役割（例えば，路面の破損，粗さ），最後に睛眼者への注意喚起のため のシンボル的な役割の 3 つの機能を有しているといわれている（Solomon, 1988, Hill and Ponder, 1977). その中で

\footnotetext{
No. 15-00410 [DOI: 10.1299/transjsme.15-00410], J-STAGE Advance Publication date : 31 March, 2016

*1 正員，金沢大学 人間社会学域（干920-1302 石川県金沢市東兼六町 2-10)

*2 東京工科大学 医療保健学部（干144-8650 東京都大田区西蒲田 5-23-22）

*3（株）キザキ（テ384-0061 長野県小諸市加増上の平 561-2）

E-mail of corresponding author: ma-yoshi@staff.kanazawa-u.ac.jp.
} 
も白杖は, 路面の破損, 粗さなど環境を知る上で有益な情報を得ることができるプローブの役割が最も重要であ るといえる．たとえば，白杖を地面にスライドさせる動的なタッチ時に生じる振動や音などは視覚障害者が環境 を知るための有益な情報源となり得るといわれている（Schenkman, 1986, Brisben et al., 1999）。そのため，過去に は白杖の性能に関寸る研究が数多く行われている. たとえば, 各材質の白杖シャフトによる柔軟性, 振動伝達性 を調べ，どのような白杖シャフトが優れているのかを論じたものや白杖の長さと重量による操作性への影響を論 じたもの（Rodegers and Wall Emerson, 2005). 白杖に伝わる振動とタッピングよって生じる音などから地面の材質 を判断することを論じたもの（Schenkman, 1986）。視覚障害者の白杖によるタッピング操作での手腕振動伝達測 定を行い，手腕における振動障害のリスクを検討したもの（Morioka and Maeda, 1998）.白杖操作における上肢の 筋負荷の影響を論じたもの (Doi et al., 2013). 白杖の構成要素の好みを調査したものがある (Ambrose-Zaken, 2005). しかしながら，これらの研究においては，白杖シャフト本体のみを対象としたものばかりであり，白杖シャフト 及びグリップ, 石突きの構成要素における総合的な機能評価をおこなった研究ではなかった. 白杖における石突 きによる段差の知覚能力を論じたものはある（Kim et al., 2009, 2010）.しかしながら，これらは白杖の操作方法に よる段差の知覚能力の比較と 2 種類の形状の石突きによる性能の評価であり必ずしも白杖の総合的な機能評価と は言えない.さらに，これらは全て成人の視覚障害者を対象としたものであり早期の白杖歩行を行なう視覚障害 児を対象とした研究ではなかった，そのため, 視覚障害児においては, 視覚障害児専用白杖としての機能性につ いては考慮されることなく，歩行支援の中で（Blasch and Del' Aune, 1992）最も有効な補助用具として学校教育の 中で使われ続けている。このような状況において, 視覚障害児が白杖歩行を行う際に使用する白杖の特性や構成 部品の性能を調べること, 視覚障害児専用白杖を開発することは非常に重要であり, それに基づいて白杖歩行指 導を行なうことにより教育効果が高まると予測される.

そこで, 本研究では全国の盲学校における白杖使用状況及び視覚障害児専用白杖の試作及び評価をおこない, 視覚障害児専用白杖に関する重要な知見を得ることを目的とした.

\section{2. 方 法}

\section{$2 \cdot 1$ 白杖に関する調査}

(1) アンケート項

本研究では, 初めに視覚障害児が使用している白杖について調査することにした. 調査対象は, 全国の盲 学校 71 校の白杖歩行指導者 (教員) に対して児童が学校で使用している白杖に関するアンケート調查をおこなっ た. 調査期間は 2012 年 4 月から 2013 年 4 月までとした. アンケート調査項目は表 1 に示す.

Table 1 The questionnaire of the long cane that was distributed to the Japanese visual impairment schools

\begin{tabular}{|c|c|c|}
\hline \multicolumn{3}{|c|}{ 1. What type of the long cane does pupil use at your school? } \\
\hline$\square$ Straight type & $\square$ Folding type & $\square$ Both Straight and Folding type \\
\hline \multicolumn{3}{|c|}{ 2. What materials are the shafts of the long cane at your school? } \\
\hline$\square$ Aluminum shaft & $\square$ Carbon shaft & $\square$ Fiberglass shaft \\
\hline \multicolumn{3}{|c|}{ 3. What type of tips does pupil use at your school? } \\
\hline$\square$ Pencil & $\square$ Roller and Pencil & $\square$ Roller, Pencil and Palm \\
\hline \multicolumn{3}{|c|}{ 4. Which part of the long cane is broken mainly? } \\
\hline$\square$ Shaft & $\square$ Tip & $\square$ Shaft and Tip \\
\hline \multicolumn{3}{|c|}{ 5. How long is the useful life of tips at your school? } \\
\hline$\square 1$ to 3 years & $\square 3$ to 5 years & $\square$ More than 5 years \\
\hline \multicolumn{3}{|c|}{ 6. What materials are the grips of the long cane at your school? } \\
\hline$\square$ Rubber grip of go & $f \square$ Plastic grip & $\square$ Other \\
\hline \multicolumn{3}{|c|}{ 7. How many hours does your school perform the long cane techniques training per a week? } \\
\hline$\square$ Between 1 and 2 & lours $\square$ Between 2 and 3 hours & $\square$ Between 3 and 4 hours \\
\hline \multicolumn{3}{|c|}{ 8. What is necessary function about the long cane? } \\
\hline ( & & $>$ \\
\hline
\end{tabular}




\section{（2）調査結果}

表 2 はアンケート調查結果を示す，視覚障害児が使用している白杖を調査するために全国の盲学校 71 校の 白杖歩行指導者に対して児童が学校で使用している白杖に関するアンケート調查をおこなった，その返答率は 83.1\%であった. 全国の盲学校に在籍する視覚障害児が使用している白杖の形式は直杖であり，62.7\%を占めてい ることがわかった．白杖シャフトに使用されている材質はグラスファイバー製とカーボン製がアルミニウム製よ り多く使用されていることがわかった．白杖用の石突は多種多様の形式が存在するが視覚障害児の白杖訓練にて 使用されている石突はペンシル型が $67.8 \%$ と主流を占めていることがわかった．さらに白杖歩行訓練の際に白杖 の一番破損寸る箇所が石突部であることもわかった。 また，石突の耐用年数は 1 年以上 3 年未満と短期間での交 換が必要であることも明らかになった．白杖用グリップに関してはゴルフ型グリップが $94.9 \%$ の割合で使用され ていることがわかった，白杖について求められる機能に関しては，長さの調整が可能で振動伝達性が優れている ことが $47.5 \%$ ，低学年用の軽量白杖が $33.9 \%$ ，石突などの機能性向上 $18.6 \%$ となっていた。 これらの結果より視 覚障害児専用白杖として求められる機能が表 3 のように明らかになった.

Table 2 Questionnaire survey result of the Japanese visual impairment school's long cane

\begin{tabular}{|c|c|c|}
\hline Number of questionnaires & $\begin{array}{r}\text { Total } \\
\text { Number }\end{array}$ & $(\%)$ \\
\hline Total & 59 & 83.1 \\
\hline \multicolumn{3}{|c|}{ 1. What type of the long cane does pupil use at your school? } \\
\hline Straight type & 37 & 62.7 \\
\hline Folding type & 7 & 11.9 \\
\hline Both Straight and Folding type & 15 & 25.4 \\
\hline \multicolumn{3}{|c|}{ 2. What materials are the shafts of the long cane at your school? } \\
\hline Aluminum shaft & 10 & 16.9 \\
\hline Carbon shaft & 25 & 42.4 \\
\hline Fiberglass shaft & 24 & 40.7 \\
\hline \multicolumn{3}{|c|}{ 3. What type of tips does pupil use at your school? } \\
\hline Pencil & 40 & 67.8 \\
\hline Roller & 8 & 13.6 \\
\hline Both Pencil, Roller and Palm & 11 & 18.6 \\
\hline \multicolumn{3}{|c|}{ 4. Which part of the long cane is broken mainly? } \\
\hline Shaft & 14 & 23.7 \\
\hline Tip & 40 & 67.8 \\
\hline Shaft and Tip & 5 & 8.5 \\
\hline \multicolumn{3}{|c|}{ 5. How long is the useful life of tips at your school? } \\
\hline 1 to 3 years & 38 & 64.4 \\
\hline 3 to 5 years & 10 & 16.9 \\
\hline More than 5 years & 11 & 18.6 \\
\hline \multicolumn{3}{|c|}{ 6. What materials are the grips of the long cane at your school? } \\
\hline Rubber grip of golf & 56 & 94.9 \\
\hline Plastic grip & 3 & 5.1 \\
\hline Other & 0 & 0.0 \\
\hline
\end{tabular}

7. How many hours does your school perform the long cane techniques training per a week

$\begin{array}{lrr}\text { Between } 1 \text { and } 2 \text { hours } & 42 & 71.2 \\ \text { Between } 2 \text { and } 3 \text { hours } & 11 & 21.2 \\ \text { Between } 3 \text { and } 4 \text { hours } & 4 & 6.8\end{array}$


8. What is necessary function about the long cane?

\begin{tabular}{lll} 
Function of length adjustment and good vibration transmissibility & 28 & 47.5 \\
Reduction in weight & 20 & 33.9 \\
Functional improvement of tip & 11 & 18.6 \\
\hline
\end{tabular}

\section{$2 \cdot 2$ 視覚障害児専用白杖の振動特性試験}

（1）視覚障害児専用白杖

アンケート調査結果より表 3 の求められる機能を参考に表 4 における白杖を株式会社キザキ（長野県小諸市） にて試作した．試作白杖は 9 本であった．シャフトの材質はアルミニウムとカーボンの 2 種類を用いた．長さは $700 \mathrm{~mm} \sim 900 \mathrm{~mm}, 600 \mathrm{~mm} \sim 900 \mathrm{~mm}$ の可動型の 2 種類とした. また，今回の白杖長さは評価試験対象児童の体格 から決定した．白杖の総重量は 159g 245g とした．石突は，ペンシル型（図 1)，ティアドロップ型（図 2），マ ッシュルーム型（図 3）の 3 種類とした. その材質には通常の石突製品に使われているジュラコンとステンレス の 2 種類を用いた．グリップの形状は，ゴルフ型を用い，材質にはクロロプレンゴムを用いた．グリップゴム硬 度は 45, 25, 15 (ASKER-C) の 3 種類とした。

Table 3 The important functions of the long cane made for the visually impaired children

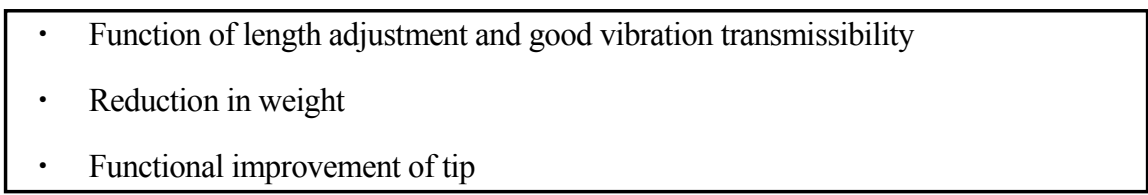

Table 4 List of the long canes made for the visually impaired children

\begin{tabular}{|c|c|c|c|c|c|c|c|c|}
\hline \multirow[t]{2}{*}{ No } & \multicolumn{2}{|c|}{$\begin{array}{l}\text { Cane shaft (Material/Diameter-thickness) } \\
\qquad(\mathrm{mm})\end{array}$} & \multirow{2}{*}{\multicolumn{3}{|c|}{$\begin{array}{c}\text { Range of cane's } \\
\text { lengths } \\
(\mathrm{mm})\end{array}$}} & \multirow{2}{*}{$\begin{array}{l}\text { Overall } \\
\text { weight } \\
\text { (g) }\end{array}$} & \multirow{2}{*}{$\begin{array}{l}\text { Tip } \\
\text { Material/Type }\end{array}$} & \multirow{2}{*}{$\begin{array}{c}\text { Grip rubber } \\
\text { hardness } \\
\text { (ASKER-C) }\end{array}$} \\
\hline & Grip side & Tip side & & & & & & \\
\hline 1 & $\begin{array}{l}\text { Aluminum } \\
\varphi 14-0.9\end{array}$ & $\begin{array}{l}\text { Aluminum } \\
\varphi 12-0.9\end{array}$ & 700 & $\sim$ & 900 & 181 & $\begin{array}{l}\text { Duracon } \\
\text { Pencil type }\end{array}$ & 25 \\
\hline 2 & $\begin{array}{l}\text { Aluminum } \\
\varphi 14-0.9\end{array}$ & $\begin{array}{l}\text { Aluminum } \\
\varphi 12-0.9\end{array}$ & 600 & $\sim$ & 900 & 195 & $\begin{array}{l}\text { Duracon } \\
\text { Mushroom type }\end{array}$ & 15 \\
\hline 3 & $\begin{array}{l}\text { Aluminum } \\
\varphi 17-0.8\end{array}$ & $\begin{array}{l}\text { Aluminum } \\
\varphi 15-1.0\end{array}$ & 700 & $\sim$ & 900 & 201 & $\begin{array}{l}\text { Duracon } \\
\text { Teardrop type }\end{array}$ & 45 \\
\hline 4 & $\begin{array}{l}\text { Aluminum } \\
\varphi 17-1.0\end{array}$ & $\begin{array}{c}\text { Carbon Fiber } \\
\varphi 15-1.0\end{array}$ & 600 & $\sim$ & 900 & 245 & $\begin{array}{l}\text { Duracon } \\
\text { Mushroom type }\end{array}$ & 45 \\
\hline 5 & $\begin{array}{l}\text { Aluminum } \\
\varphi 17-1.0\end{array}$ & $\begin{array}{l}\text { Carbon Fiber } \\
\varphi 14-1.0\end{array}$ & 700 & $\sim$ & 900 & 211 & $\begin{array}{l}\text { Duracon+SUS } \\
\text { Pencil type }\end{array}$ & 15 \\
\hline 6 & $\begin{array}{l}\text { Aluminum } \\
\varphi 17-1.0\end{array}$ & $\begin{array}{l}\text { Carbon Fiber } \\
\varphi 14-1.0\end{array}$ & 600 & $\sim$ & 900 & 222 & $\begin{array}{l}\text { Duracon+SUS } \\
\text { Teardrop type }\end{array}$ & 25 \\
\hline 7 & $\begin{array}{c}\text { Carbon Fiber } \\
\varphi 16-0.8\end{array}$ & $\begin{array}{c}\text { Carbon Fiber } \\
\varphi 14-1.0\end{array}$ & 700 & $\sim$ & 900 & 184 & $\begin{array}{l}\text { Duracon } \\
\text { Pencil type }\end{array}$ & 45 \\
\hline 8 & $\begin{array}{c}\text { Carbon Fiber } \\
\varphi 16-0.8\end{array}$ & $\begin{array}{c}\text { Carbon Fiber } \\
\varphi 14-1.0\end{array}$ & 600 & $\sim$ & 900 & 225 & $\begin{array}{l}\text { Duracon } \\
\text { Mushroom type }\end{array}$ & 25 \\
\hline 9 & $\begin{array}{c}\text { Carbon Fiber } \\
\varphi 16-0.8\end{array}$ & $\begin{array}{c}\text { Carbon Fiber } \\
\varphi 10.8-1.0\end{array}$ & 700 & $\sim$ & 900 & 159 & $\begin{array}{c}\text { Duracon } \\
\text { Teardrop type }\end{array}$ & 15 \\
\hline
\end{tabular}




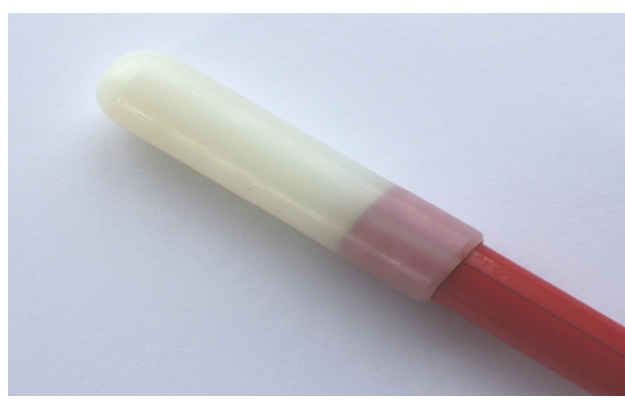

Fig.1 Pencil tip. The type of cane tip.

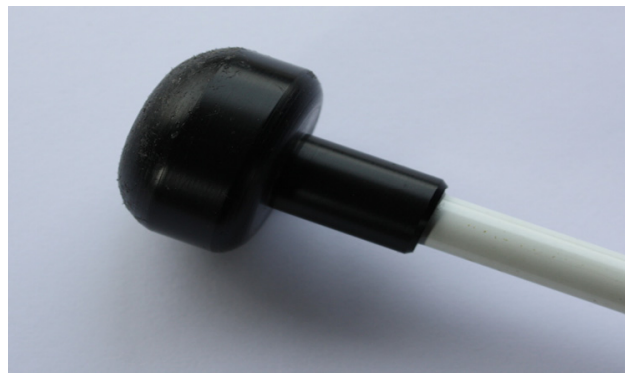

Fig. 3 Mushroom tip. The type of cane tip.

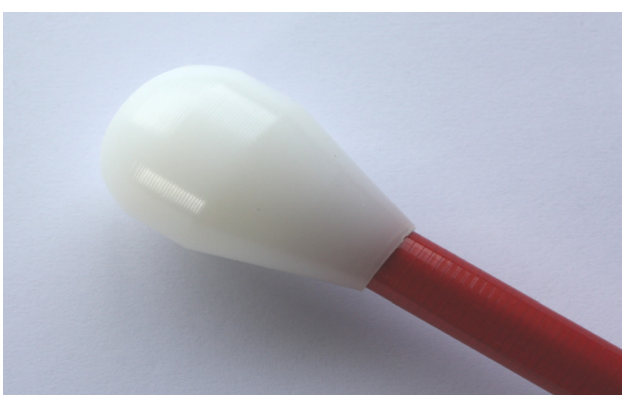

Fig.2 Teardrop tip. The type of cane tip.

\section{(2) 振動特性試験方法}

表 3 より試作した視覚障害児専用白杖に求められる性能として振動伝達性がある。そこで加振点移動法による 各白杖の固有振動数測定を行なった。 図 4 は加振点移動法による振動計測実験装置である. 白杖にはピエゾ型 3 軸加速度計 (Type 4507-B-004 Brüel \& Kjær) が取り付けられる．インパルスハンマ（ENDEVCO : Brüel \& Kjær）を 使って予め決められた加振点に振動を加える. その振動信号はデータ集積装置（TYPE PULS 3109：Brüel \& $\mathrm{Kjær}$ )に集められる.サンプリング周波数は $2000 \mathrm{~Hz}$ である.このデータを解析ソフト (PULSE Labshop version 10.1 Modal Test Consultant: Brüel \& Kjær)により 固有振動数を FFT により算出する．また，図 5 は加振点移動法による 加振点及びピエゾ型 3 軸加速度計 (Type 4507-B-004 Brüel \& Kjær) の取り付け位置を示す.

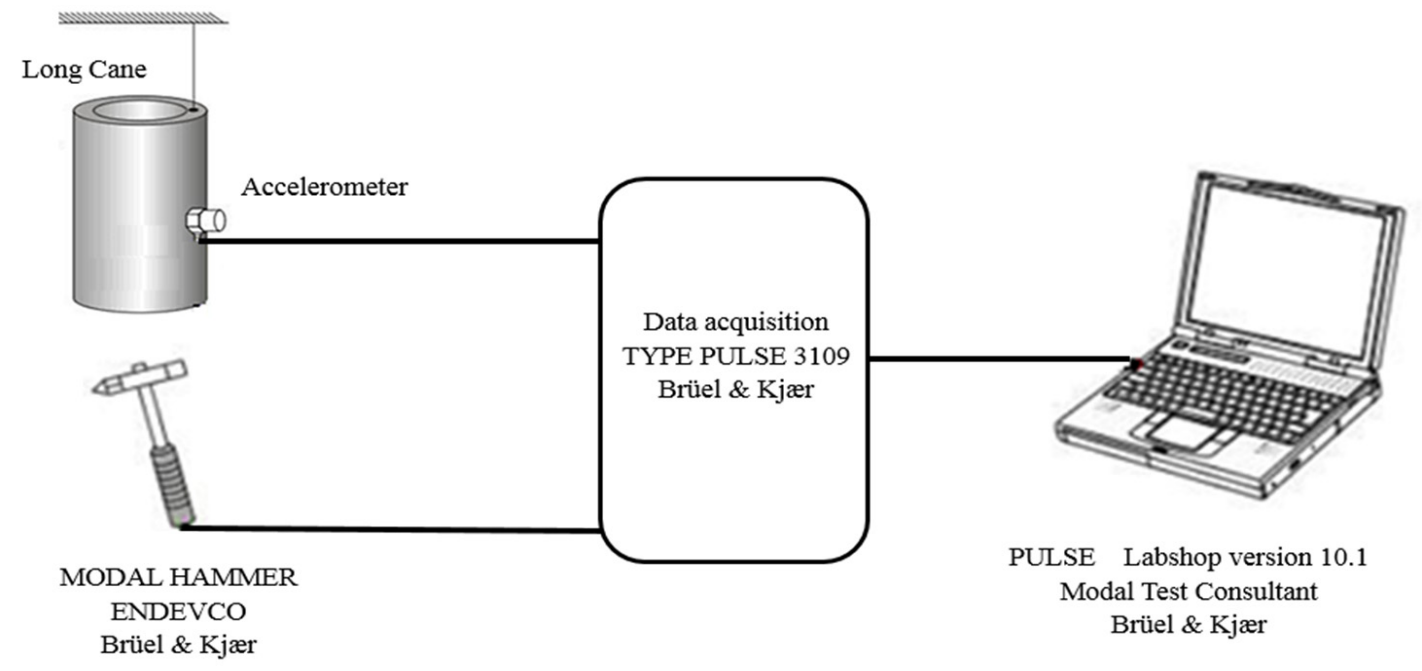

Fig.4 Vibration experimental apparatus. An experimental apparatus is presented for getting of accurate frequency response function. The vibration of the long cane is detected by 3 -axis acceleration sensor, and vibration information is extracted from a vibration signal based on FFT analysis. 


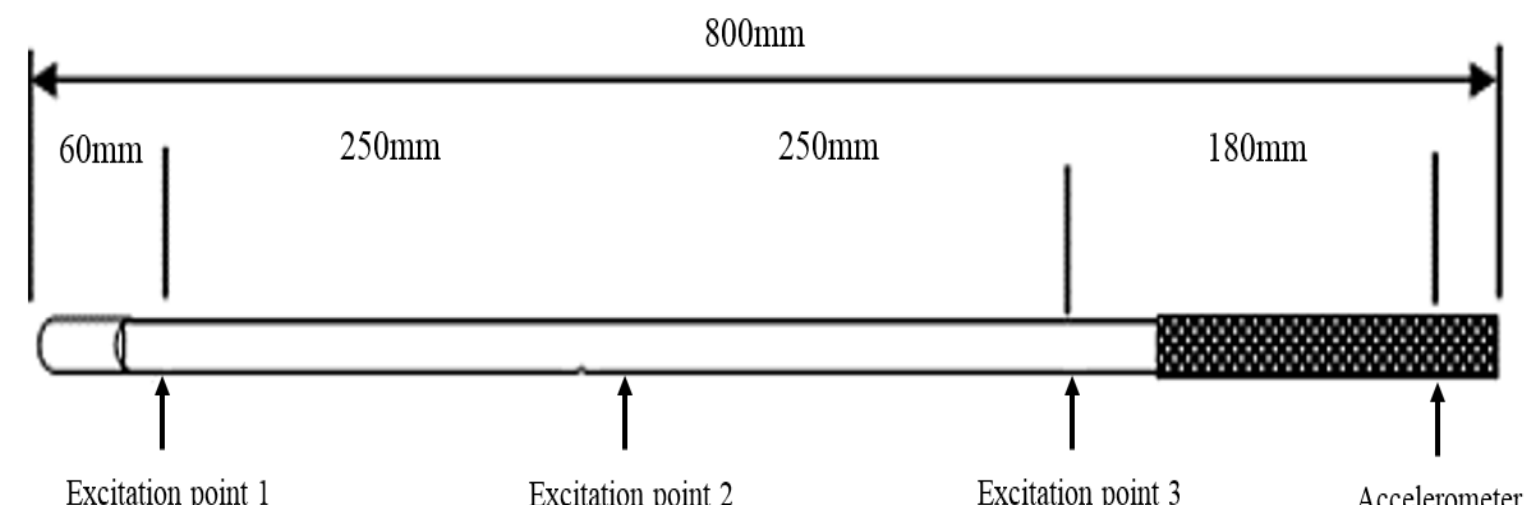

Fig. 5 Excitation point and 3-axis acceleration sensor fixed position. An excitation point in one point of the cane is excited, and a transfer function between the excitation point and an accelerometer sensor point on the object to be measured is measured.

(3) 振動特性試験結果

表 5 は視覚障害児専用白杖における固有振動数測定結果を示す．シャフト材質がアルミニウムでは，軽量な シャフトほど固有振動数が高くなることが明らかになった. また，カーボンの場合も同様の傾向が見られた. アルミニウムとカーボンを比較した場合, カーボン材質のシャフトの方がアルミニウムシャフトより固有振動 数が高いことが明らかになった．以上より白杖シャフトとして振動特性が高い材質は軽量でカーボン製である ことが明らかになった。

Table 5 Natural frequencies of vibration of the long canes

\begin{tabular}{cccccc}
\hline & Long cane shaft & & Natural frequency & (Hz) \\
\hline Grip side & Tip side & $\begin{array}{c}\text { Weight } \\
(\mathrm{g})\end{array}$ & $\begin{array}{c}\text { First frequency } \\
(\mathrm{Hz})\end{array}$ & $\begin{array}{c}\text { Second frequency } \\
(\mathrm{Hz})\end{array}$ \\
\hline $\begin{array}{c}\text { Aluminum } \\
\varphi 14-0.9\end{array}$ & $\begin{array}{c}\text { Aluminum } \\
\varphi 12-0.9\end{array}$ & 181 & 57 & 119 & 244 \\
Aluminum & $\begin{array}{c}\text { Carbon Fiber } \\
\varphi 16-0.8\end{array}$ & 222 & 32 & 114 & 265 \\
$\begin{array}{c}\text { Carbon Fiber } \\
\varphi 16-0.8\end{array}$ & $\begin{array}{c}\text { Carbon Fiber } \\
\varphi 14-1.0\end{array}$ & 184 & 77 & 122 \\
\hline
\end{tabular}

\section{$2 \cdot 3$ 視覚障害児専用白杖の評価}

（1）視覚障害児専用白杖に対寸る官能検査

本実験では試作した視覚障害児専用白杖の操作性の感覚の主観的申告結果を得るために意味測定法 (Semantic Differential Technique: 以下 SD 法)による視覚障害児専用白杖操作時の長さ, 重量, 振動感覚, 石 突・グリップ操作性とこれらを総合した “使い易さ” の感覚から成る 5 項目を 6 段階に表現する官能検查を行 った. 実験は，盲学校にて週 1 時間行なわれている白杖歩行訓練（自立活動）の授業で行われた. 最初に児童 は，開発した視覚障害児専用白杖（No. 1 から No.9）の昇順に使用する昇順群と（No.9から No.1）の降順に使 用寸る降順群に分けられた，その各群に従って使用した白杖を児童が 1 ケ月間にある白杖歩行訓練の授業 4 時 間（各週 1 時間）に使用し，評価をおこなった．全児童が評価期間中に 9 本すべての種類の白杖を使用するこ ととした. 児童が 9 本すべての白杖の試行終了後に教師が児童に対してインタビュー形式にてアンケート評価 をおこなった．白杖使用環境は学校内のリノリウム床及び学校周辺のアスファルト路面とした．評価期間は 2014 年 5 月から 2015 年 3 月とした. 被験者は先天性の視覚障害のみであり, その他の疾患が無い児童 (年齢 8 歳から 12 歳), (男子 1 名, 女子 9 名）合計 10 名とした. 
(2) 結 果

本実験では, 視覚障害児専用白杖操作時の長さ, 重量, 振動感覚, 石突・グリップ操作性において官能検 查を行った，その回答結果において，児童が視覚障害児専用白杖に関寸る各項目の評価を行う際に白杖の使 用順によって，児童の評価が影響するかどうかについて Pearson のカイ 2 乗検定により順序効果を調べた. その結果，いずれの項目においても使用順における順序効果は見られなかった（表 6 , 表 7 , 表 8 , 表 9 , 表 10). 図 6 から図 9 は, SD 法による 10 名の被験者の主観的申告に基づく視覚障害児専用白杖使用時の各項 目における使用感覚の平均評価值を示寸，ここで，使用感覚の評価值は，+3 を「非常に良い, +2 を「かな り良い, +1 を「良い」, -1 を「悪い」，-2を「かなり悪い」，-3 を「非常に悪い」とそれぞれ定義し，6段階 に分類した. 本研究では 9 種類の白杖を試作した。試作白杖は長さの調整可能な 2 種類のタイプ $(600 \mathrm{~mm}$ か ら 900mm, 700mm から 900mm）を製作した. 一般的に白杖操作に適した長さは靴を履いて直立した姿勢で, 床から剣状突起より少し上と言われている，しかしながら，成長が著しい視覚障害児の体格および歩速は 日々変化しており, 長さの調整機能が無い直杖では白杖操作に適した長さに調整できず白杖訓練の学習効果 が得られないと推測し, 上記の可動範囲機能を持つ振り出し式の白杖とした. その結果, 図 6 より身長が $120 \mathrm{~cm}$ から $129 \mathrm{~cm}$ の被験者では $750 \mathrm{~mm} ， 130 \mathrm{~cm}$ から $139 \mathrm{~cm}$ では $850 \mathrm{~mm}, 140 \mathrm{~cm}$ から $149 \mathrm{~cm}$ では $900 \mathrm{~mm}$ の 白杖長さにおいて一番評価が高かった。これにより, 成長著しい学齢期の視覚障害児に対して, 身長に応じ た白杖の長さに調整可能な機能が必要であることが明らかになった。図 7 は白杖の重量に関しての使用感覚 における評価を示したものである. この結果より白杖の重量が 201g を境に重量に対する評価が大きく変わ ることが明らかになった。 また, 図 8 では被験者の白杖操作手の握力平均值 $10 \mathrm{~kg}$ をもとに使用感覚におけ る評価をおこなった，その結果，握力が $10 \mathrm{~kg}$ 以下の被験者群は握力が $10 \mathrm{~kg}$ 以上の被験者群より重量におけ る白杖操作時の使用感覚における評価において影響が受けやすいことが明らかになった．図 9 は石突・白杖 シャフト材質・グリップの硬さにおける振動伝達性による使用感覚の評価をおこなった．横軸は石突の種類 順にマッシュルーム型(Mushroom), ティアドロップ型(Teardrop), ペンシル型(Pencil)に表示した. また, 同種 の石突間ではグリップの硬さの值を昇順に表示寸ることとした．縦軸はその振動伝達性の評価值である．そ の結果, 石突は, マッシュルーム型(Mushroom), ティアドロップ型(Teardrop), ペンシル型(Pencil)の順に振動 伝達性における使用感覚の評価值が高くなることがわかった．また，同種の石突間においては，グリップの 硬さの值が高くなるほど振動伝達性における使用感覚の評価值が高くなることがわかった。これにより，グ リップの硬度と石突の組み合わせが白杖使用者の振動伝達性における使用感覚の評価に関係していること が判明した.

Table 6 Effects of response order effect on cane's length

\begin{tabular}{ccccc}
\hline $\begin{array}{c}\text { Length } \\
(\mathrm{mm})\end{array}$ & $\begin{array}{c}\text { Pearson } \\
\chi^{2} \text {-statistic }\end{array}$ & $\begin{array}{c}\text { Data } \\
\text { point }\end{array}$ & Degree of freedom & significance level \\
\hline 600 & 0.53 & 10 & 2 & n.s. \\
650 & 6.80 & 10 & 3 & n.s. \\
700 & 4.33 & 10 & 3 & n.s. \\
750 & 1.33 & 10 & 3 & n.s. \\
800 & 1.33 & 10 & 3 & n.s. \\
850 & 5.00 & 10 & 4 & n.s. \\
900 & 4.00 & 10 & 3 & n.s. \\
\hline & & & & $* P<.05$
\end{tabular}

Table 8 Effects of response order effect on vibration

\begin{tabular}{ccccc}
\hline Vibration & $\begin{array}{c}\text { Pearson } \\
\chi^{2} \text {-statistic }\end{array}$ & Data point & Degree of freedom Significance level \\
\hline No.1 & 0.48 & 10 & 1 & n.s. \\
No.2 & 5.33 & 10 & 3 & n.s. \\
No.3 & 0.48 & 10 & 1 & n.s. \\
No.4 & 1.67 & 10 & 1 & n.s. \\
No.5 & 0.48 & 10 & 1 & n.s. \\
No.6 & 0.67 & 10 & 2 & n.s. \\
No.7 & 2.50 & 10 & 1 & n.s. \\
No.8 & 1.67 & 10 & 1 & n.s. \\
No.9 & 4.33 & 10 & 2 & n.s. \\
\hline & & & & $* .05$
\end{tabular}

Table 7 Effects of response order effect on cane's weight

\begin{tabular}{ccccc}
\hline $\begin{array}{c}\text { Weight } \\
(\mathrm{g})\end{array}$ & $\begin{array}{c}\text { Pearson } \\
\chi^{2} \text {-statistic }\end{array}$ & $\begin{array}{c}\text { Data } \\
\text { point }\end{array}$ & Degree of freedom & significance level \\
\hline 159 & 0.48 & 10 & 1 & n.s. \\
181 & 0.48 & 10 & 1 & n.s. \\
184 & 0.48 & 10 & 1 & n.s. \\
195 & 0.48 & 10 & 1 & n.s. \\
201 & 0.48 & 10 & 1 & n.s. \\
211 & 0.48 & 10 & 1 & n.s. \\
222 & 3.60 & 10 & 1 & n.s. \\
225 & 1.67 & 10 & 2 & n.s. \\
245 & 1.33 & 10 & 2 & n.s. \\
\hline
\end{tabular}

Table 9 Effects of response order effect on cane's tip

\begin{tabular}{ccccc}
\hline Tip & $\begin{array}{c}\text { Pearson } \\
\chi^{2} \text {-statistic }\end{array}$ & Data point & Degree of freedom Significance level \\
\hline No.1 & 0.48 & 10 & 1 & n.s. \\
No.2 & 1.67 & 10 & 1 & n.s. \\
No.3 & 0.40 & 10 & 1 & n.s. \\
No.4 & 1.67 & 10 & 1 & n.s. \\
No.5 & 0.40 & 10 & 1 & n.s. \\
No.6 & 2.67 & 10 & 3 & n.s. \\
No.7 & 0.48 & 10 & 1 & n.s. \\
No.8 & 1.67 & 10 & 1 & n.s. \\
No.9 & 1.67 & 10 & 1 & n.s. \\
\hline & & & & $* P<.05$
\end{tabular}


Yoshioka, Shimizu, Kizaki and Nakao, Transactions of the JSME (in Japanese), Vol.82, No.836 (2016)

Table 10 Effects of response order effect on cane's weight

\begin{tabular}{ccccc}
\hline Grip & $\begin{array}{c}\text { Pearson } \\
\chi^{2} \text {-statistic }\end{array}$ & $\begin{array}{c}\text { Data } \\
\text { point }\end{array}$ & Degree of freedom & Significance level \\
\hline No.1 & 1.67 & 10 & 1 & n.s. \\
No.2 & 5.33 & 10 & 3 & n.s. \\
No.3 & 0.48 & 10 & 1 & n.s. \\
No.4 & 4.67 & 10 & 3 & n.s. \\
No.5 & 2.50 & 10 & 1 & n.s. \\
No.6 & 3.80 & 10 & 2 & n.s. \\
No.7 & 2.50 & 10 & 1 & n.s. \\
No.8 & 6.80 & 10 & 3 & n.s. \\
No.9 & 1.67 & 10 & 2 & n.s. \\
\hline & & & & $* P<.05$
\end{tabular}

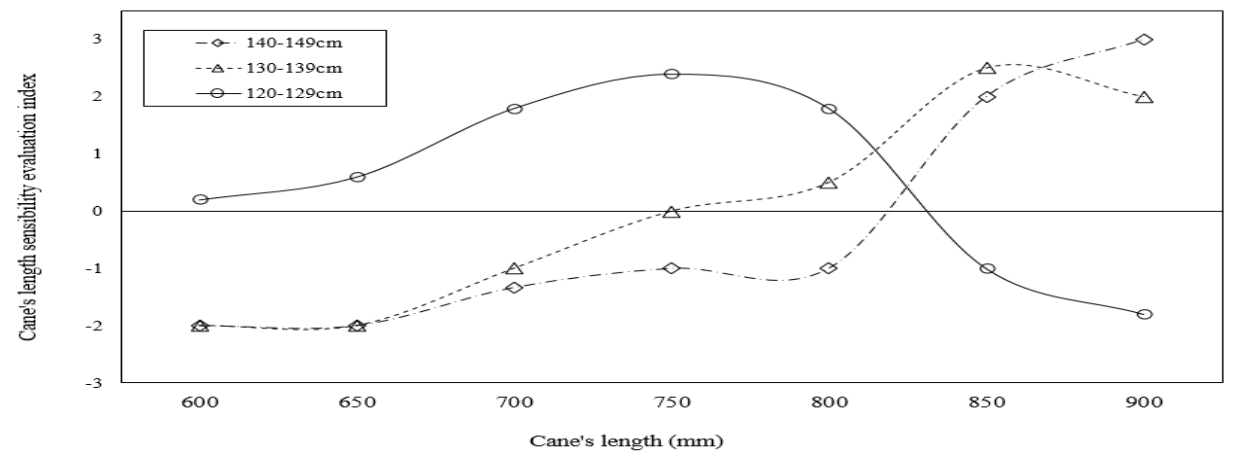

Fig. 6 Length characteristics by semantic differential technique

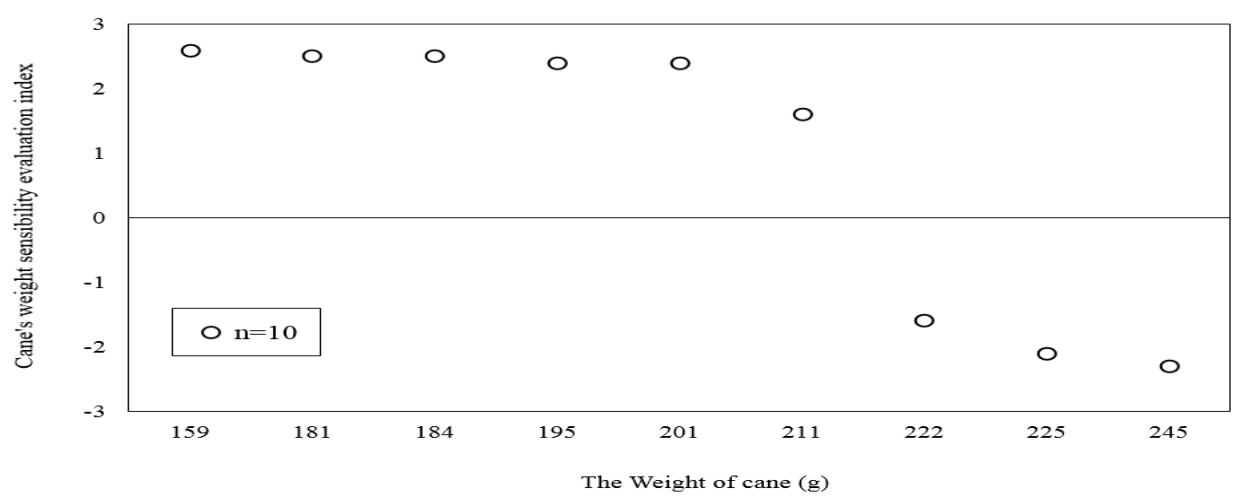

Fig. 7 Cane's weight characteristics by semantic differential technique

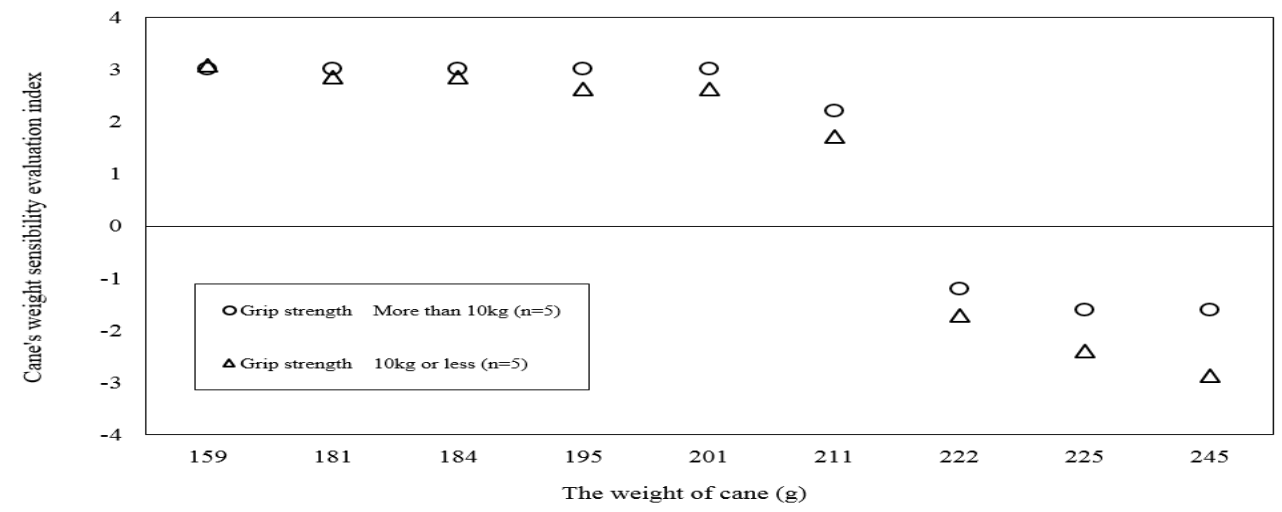

Fig. 8 Grip strength characteristics by semantic differential technique 


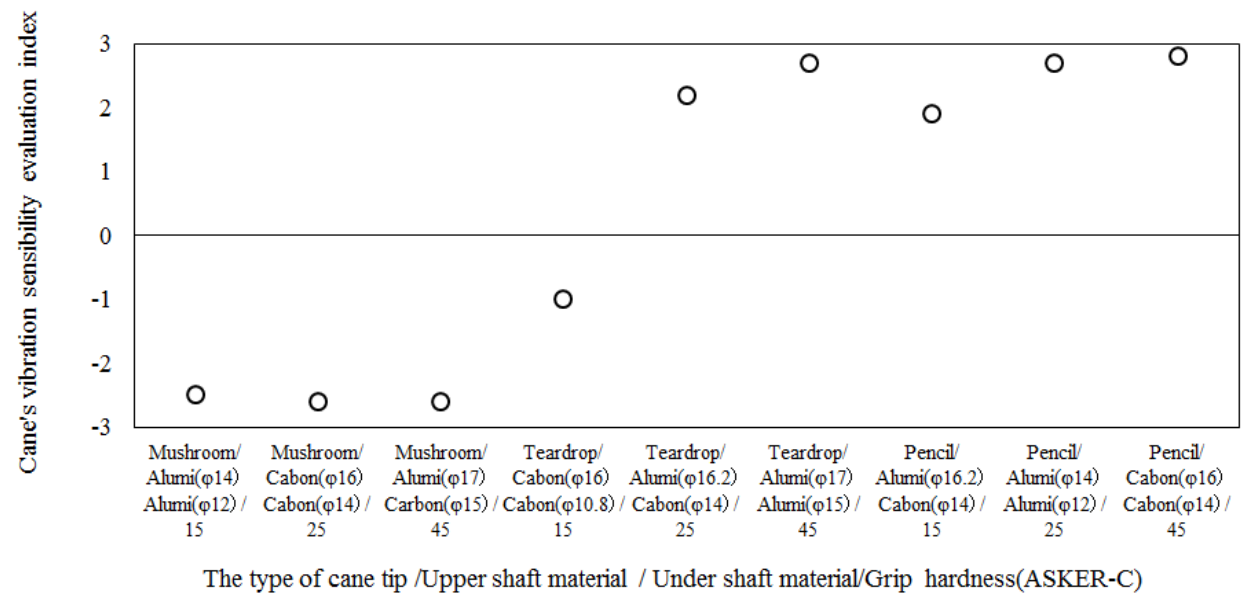

Fig. 9 Vibration characteristics (Tip-Shaft material-Grip hardness) by semantic differential technique

\section{3. 倫理的配慮}

本研究においては全ての対象者の保護者に研究に関する全ての事項について説明をおこない，同意を得た．そ の後, 被験者に口頭にて説明し, 同意を得た. また，実験プロトコルはヘルシンキ宣言に沿って行なわれた。

\section{4. 総合結果と考察}

本研究では全国の盲学校における白杖使用状況及び視覚障害児専用白杖の試作及び評価をおこなった. その結 果, 視覚障害児専用白杖に関する重要な知見を得た. 白杖使用状況に関する調查結果（表 2）からは，全国の盲 学校で使用されている白杖の形式は直杖が $62.7 \%$ 占める結果となり，一般的に成人が使用している白杖の形式 とは殆ど変わらなかったこと．また，白杖の材質に関してはアルミニウム製からグラスファイバー製とカーボン 製の新しい材質に変わってきたことが明らかになった．石突はペンシル型，ティアドロップ型，マッシュルーム 型など多種多様な形式が存在しており，通常は歩行訓練士が視覚障害者と話し合いながら白杖歩行に適したもの を提案している。しかしながら，現在の教育現場においては主にペンシル型が使用されていることが明らかにな った.

視覚障害児専用白杖の試作及び評価において白杖の長さに関しては, 成長著しい学齢期の視覚障害児に対して, 身長に応じて白杖の長さを調整できる機能が必要であることが明らかになった．また，その際の長さの調整基準 としては，従来，成人用白杖の長さを決定する際に用いられている「靴を履いて直立した姿勢で，床から剣状突 起より少し上」が適しているように思われる．視覚障害児に関しては白杖重量が $200 \mathrm{~g}$ を超えると白杖の操作性 に影響することが示された．（Rodegers and Wall Emerson, 2005）らは白杖の長さと重量が白杖のパフォーマンスに ぞの程度影響するのかを論じた，それによると重い白杖を長い間使用すると使用者の疲労を増大させる可能性が あることを結論付けた. 本研究においても握力と白杖の重量において白杖操作性の評価をおこなった. その結果, 握力と白杖の重量には白杖操作性の評価に大きく影響することが判明した．このような点からも彼らの実駼結果 を支持するものといえる．グリップと石突に関しては，グリップの硬度と石突の組み合わせが白杖使用者の振動 伝達性における使用感覚の評価に大きく関係していることが明らかになった. (Kim et al., 2010) は，白杖の石突の 種類と操作方法について論じたそその中で白杖使用者の特性と歩行環境に適した石突の種類と白杖操作方法を選 択することが重要であると述べている．（LaGrow et al., 1988) は，石突のペンシル型，マシュマロ型，カーブ型い ずれの形も操作性に関する違いはないが, 白杖使用者がカーブ型の石突を圧倒的に好む傾向があると論じている. 本研究では, 白杖使用者が石突を選択寸る場合, 石突の操作性の観点から選択寸るのではなく, 石突とグリップ の硬度の組み合わせが選択の際に重要である可能性を明らかにした. 
以上より視覚障害児用白杖とは，シャフトの材質よりも児童の身体的特性に適する重量と長さ及び石突，グリ ップから伝わる振動伝達性が重要な構成要素であると示唆された。 また，視覚障害児の白杖歩行訓練では，白杖 の石突部を常に路面に接地させ，操作者の体の幅よりやや広い範囲で白杖を一定のリズムで左右にスライドする コンスタント・コンタクト・テクニックを用いている．この操作法は，石突が常に路面に接地してあるため， 凹 凸の少ない平滑な場所で用いられる. 加えて, 操作者は路面の状況を白杖本体から伝わる振動により環境認知し やすい操作法でもある. それゆえ，視覚障害児の白杖歩行学習では一般的に適した方法と言われている（Lance, 1987). 一方, 路面の凹凸が激しい場所では視覚障害者・児が白杖操作する場合, 手首を支点として左右均等に肩 幅よりやや広めに石突が路面から数センチ持ち上がるような弧を描くように白杖を操作するツー・ポイント・タ ッチ・テクニックが用いられている.

今回の実験では，視覚障害児はコンスタント・コンタクト・テクニックを用いて視覚障害児用白杖を操作し評 価をおこなった，そのため, 路面の凹凸が激しい場所で用いられる白杖操作法であるツー・ポイント・タッチ・ テクニックによる障害児用白杖の評価試験は行っていない. また, ツー・ポイント・タッチ・テクニックは, 白 杖の操作法, 路面から白杖本体に伝わる振動強度においてコンスタント・コンタクト・テクニックとは異なって いる (Kim et al., 2010)．それゆえ，今後は，ツー・ポイント・タッチ・テクニックによる視覚障害児専用白杖にお ける官能評価試験を行うことや多くの被験者に評価していただくことが今後の課題といえる.

\section{謝 辞}

本研究は, 公益財団法人 三菱財団 社会福祉事業 研究助成金にて行なわれた. この場をお借りして感謝申し上 げます. また, 愛知県立名古屋盲学校 上杉 相良先生, 池田 明子先生並びに全国の盲学校の諸先生方には大変お 世話になりました．有難うございました。

\section{文 献}

Ambrose-Zaken, G., Knowledge of and preferences for long cane components: a qualitative and quantitative study. Journal of Visual Impairment \& Blindness, Vol.99(2005), pp.633-645.

Ball, M.J., Mobility in perspective, Blindness, AAWB Annual(1964), pp.107-141.

Blasch, B.B. and De l'Aune, W., A computer profile of mobility coverage and a safe index, Journal of Visual Impairment \& Blindness, Vol.86(1992), pp.249-254.

Brisben, A.J., Hisano, S.S. and Johnson, K.O., Detection of vibration transmitted through an object grasped in the hand, Journal of Neurophysiology, Vol.81(1999), pp.1548-1558.

Doi, K., Sugama, A., Nishimura, T., Ino, S., Nunokawa, K., Sugiyama, M., Kosuge, K. and Miyazaki, A., Influence of the weight of white canes on muscle load of the upper limbs, World Congress on Medical Physics and Biomedical Engineering, IFMBE Proceedings, Vol.39(2013), pp.2019-2022.

Foulke, E., The development of an improved cane for use by blind pedestrians, in perceptual alternatives laboratory, Annual report to thedean of the Graduate School 1, 1974 through June 30(1975), pp.57-69.

Hill, E.W. and Ponder, P., Orientation and mobility techniques, guide for the practitioner, New York, American Foundation for the Blind(1977).

Hoover, R.E., Foot travel at Valley Forge. New outlook for the blind and the teachers forum, Vol.40(1946), pp.246-251.

Hoover, R.E., The cane as a travel aid, In P.A.Zahl(Ed.), Blindness(2nd ed.)(1962), pp.353-365.

Kim, D., Wall Emerson, R.S. and Curtis, A.B., Drop-off detection with the long cane: effects of cane tips and techniques, Human Factors, Vo.1.52, No.3 (2010), pp.456-465.

Kim, D., Wall Emerson, R.S. and Curtis, A.B., Drop-off detection with the long cane: effects of different cane techniques on performance, Journal of Visual Impairment \& Blindness, Vol.103(2009), pp.519-530.

LaGrow, S.J., Kjeldstad, A. and Lewandowski, E., The effects of cane-tip design on three aspects of nonvisual travel, Journal of Visual Impairment \& Blindness, Vol.82(1988), pp.13-16.

Lance, P., To the editor, Journal of Visual Impairment \& Blindness, Vol.81(1987), pp.143-145.

Morioka, M. and Maeda, S., Measurement of hand-transmitted vibration of tapping the long cane for visually handicapped people in Japan, Industrial Health, Vol.36(1998), pp.179-190.

Rodegers, M.D. and Wall Emerson, R., Human factor analysis of long cane design: weight and length, Journal of Visual 
Impairment \& Blindness, Vol.99(2005), pp.622-632.

Schenkman, B.N., Identification of ground materials with the aid of tapping sounds and vibrations of long canes for the blind, Ergonomics, Vol.29(1986), pp.985-998.

Solomon, H.Y., Movement produced invariants in haptic explorations, An example of a self-organizing, information-driven, intentional system, Human Movement Science, Vol.7(1988), pp.201-223.

八高隆雄，山本圭治郎，小山昌洋，兵頭和人，円筒物体把握における握り易さの感性評価，日本機械学会論文集， C 編, Vol.62, No.602(1996), pp.3999-4004.

\section{References}

Ambrose-Zaken, G., Knowledge of and preferences for long cane components: a qualitative and quantitative study. Journal of Visual Impairment \& Blindness, Vol.99(2005), pp.633-645.

Ball, M.J., Mobility in perspective, Blindness, AAWB Annual(1964), pp.107-141.

Blasch, B.B. and De l'Aune, W., A computer profile of mobility coverage and a safe index, Journal of Visual Impairment \& Blindness, Vol.86(1992), pp.249-254.

Brisben, A.J., Hisano, S.S. and Johnson, K.O., Detection of vibration transmitted through an object grasped in the hand, Journal of Neurophysiology, Vol.81(1999), pp.1548-1558.

Doi, K., Sugama, A., Nishimura, T., Ino, S., Nunokawa, K., Sugiyama, M., Kosuge, K. and Miyazaki, A., Influence of the weight of white canes on muscle load of the upper limbs, World Congress on Medical Physics and Biomedical Engineering, IFMBE Proceedings, Vol.39(2013), pp.2019-2022 (in Japanese).

Foulke, E., The development of an improved cane for use by blind pedestrians, In perceptual alternatives laboratory, Annual report to thedean of the Graduate School 1, 1974 through June 30(1975), pp.57-69.

Hill, E.W. and Ponder, P., Orientation and mobility techniques, guide for the practitioner, New York, American Foundation for the Blind(1977).

Hoover, R.E., Foot travel at Valley Forge. New outlook for the blind and the teachers forum, Vol.40(1946), pp.246-251.

Hoover, R.E., The cane as a travel aid, In P.A.Zahl(Ed.), Blindness(2nd ed.)(1962), pp.353-365.

Kim, D., Wall Emerson, R.S. and Curtis, A.B., Drop-off detection with the long cane: effects of cane tips and techniques, Human Factors, Vo.1.52, No.3 (2010), pp.456-465.

Kim, D., Wall Emerson, R.S. and Curtis, A.B., Drop-off detection with the long cane: effects of different cane techniques on performance, Journal of Visual Impairment \& Blindness, Vol.103(2009), pp.519-530.

LaGrow, S.J., Kjeldstad, A. and Lewandowski, E., The effects of cane-tip design on three aspects of nonvisual travel, Journal of Visual Impairment \& Blindness, Vol.82(1988), pp.13-16.

Lance, P., To the Editor, Journal of Visual Impairment \& Blindness, Vol.81(1987), pp.143-145.

Morioka, M. and Maeda, S., Measurement of hand-transmitted vibration of tapping the long cane for visually handicapped people in Japan, Industrial Health, Vol.36(1998), pp.179-190 (in Japanese).

Rodegers, M.D. and Wall Emerson, R., Human factor analysis of long cane design: weight and length, Journal of Visual Impairment \& Blindness, Vol.99(2005), pp.622-632.

Schenkman, B.N., Identification of ground materials with the aid of tapping sounds and vibrations of long canes for the blind, Ergonomics, Vol.29(1986), pp.985-998.

Solomon, H.Y., Movement produced invariants in haptic explorations, An example of a self-organizing, information-driven, intentional system, Human Movement Science, Vol.7(1988), pp.201-223.

Yakou, T., Yamamoto, K., Koyama, M. and Hyoudo, K., Sensory evaluation of grip using cylindrical objects, Transactions of the Japan Society of Mechanical Engineers, Series C, Vol.62, No.602 (1996), pp.3999-4004. 